A N N A L ES

UNIVERSITATIS MARIAE CURIE-SKŁODOWSKA

LUBLIN - POLONIA

VOL. LXII, 2

SECTIO G

2015

\title{
RADOSŁAW PACUD
}

\section{Sprawiedliwość w prawie emerytalnym. Kwestie międzypokoleniowe oraz ekonomiczne}

Justice in Pension Insurance. Inter-Generation and Economical Questions

\section{O SPRAWIEDLIWOŚCI W PRAWIE EMERYTALNYM}

Tematem wiodącym wielu opracowań naukowych zebranych w publikacji jest sprawiedliwość, stąd należy podjąć refleksję także w przedmiocie sprawiedliwości w prawie emerytalnym. Najbardziej doniosły problem, który wymaga oceny z punktu widzenia sprawiedliwości, wydaje się dotyczyć aspektów międzypokoleniowych ubezpieczenia emerytalnego, związanych z ekonomicznym zjawiskiem wspierania pokolenia obecnych emerytów przez pokolenie przyszłych emerytów za pomocą mechanizmów finansowania repartycyjnego ubezpieczenia emerytalnego.

Podjęcie tak określonego tematu wymaga rozpoczęcia od rozważań na temat znaczenia sprawiedliwości. Zacznijmy od klasycznego podziału na sprawiedliwość formalną i materialną. Sprawiedliwość formalną rozumie się w ten sposób, że osoby należące do tej samej grupy traktowane są tak samo. Takie rozumienie sprawiedliwości praktycznie odpowiada zasadzie równości. Pogląd taki znajduje oparcie w orzecznictwie Trybunału Konstytucyjnego'. Ze sprawiedliwością

1 W wyroku TK z dnia 17 czerwca 2014 roku (sygn. akt P 6/12, OTK 62/6/A/2014) rozróżniono obowiązki formalne i materialne na kanwie zasad sprawiedliwości społecznej z art. 2 Konstytucji, która konkretyzuje immanentną dla systemu prawa cechę sprawiedliwości. Przyjmuje się w tym orzeczeniu, że treść zasady sprawiedliwości społecznej jest ogólniejsza i bogatsza od zasady równości. Z jednej strony ma wyznaczać obowiązki o charakterze formalnym, nakazując równe traktowanie podmiotów równych. W tym aspekcie zasada sprawiedliwości społecznej w zasadzie pokrywa się z zasadą równości, będącą jej konkretyzacją. Z drugiej zaś wyznacza obowiązki o charakterze materialnym, sprowadzające się do nakazu realizacji i ochrony szeregu wartości konstytucyjnych, w tym solidarności społecznej czy bezpieczeństwa socjalnego (podobnie wyrok TK o sygn. K 9/12 i powołane tam orzecznictwo). 
formalną w prawie emerytalnym związany jest problem aksjologiczny i psychologiczno-społeczny wynikający z tego, że istnieje wiele grup o zróżnicowanej sytuacji socjalnej. Odrębne lub preferencyjne reguły narastania i nabywania uprawnień emerytalnych dla rolników, górników, sędziów, prokuratorów i nauczycieli odpowiadają zasadzie równości, gdyż każda osoba z tej grupy powinna być traktowana $\mathrm{w}$ taki sam sposób przy stosowaniu prawa ${ }^{2}$. Nadmiar tych grup oraz podkreślana w dyskursie społecznym i ekonomicznym liczba tzw. przywilejów emerytalnych rodzi jednak poczucie niesprawiedliwości z uwagi na nierówności i brak wzajemnego zrozumienia dla podstaw kształtowania grup o różnej sytuacji prawno-socjalnej w prawie emerytalnym ${ }^{3}$. Kwestie braku sprawiedliwości przez nadmierną lub niewystarczającą dyferencję uprawnień (konstytucyjny nakaz „równego traktowania równych”) są rozstrzygalne na gruncie orzecznictwa Trybunału Konstytucyjnego ${ }^{4}$. Organ ten w ograniczony sposób kształtuje przekonania w społeczeństwie, z którego rodzić się może wola zmian w prawie, a także w samej Konstytucji. Poza tą kwestią, związaną również ze stosowaniem zasady równości, nie ma chyba większych problemów ze sprawiedliwością formalną, która urzeczywistnia się, gdy każdemu przyznaje się to, co zostało przewidziane prawem. Jedynie liczba przewlekłych postępowań sądowych w sprawach z zakresu ubezpieczeń społecznych może stanowić miarę braku pełnej realizacji sprawiedliwości formalnej w prawie emerytalnym.

Wyjaśnienie kwestii sprawiedliwości materialnej w ubezpieczeniu emerytalnym jest dużo bardziej złożone i problematyczne. Wielu komentatorów będzie bronić określonego kształtu systemu emerytalnego de lege lata, co potwierdza, że sprawiedliwe formalnie rozwiązania ubezpieczenia emerytalnego spełniają cechy sprawiedliwości materialnej. Sporo osób jednak może kwestionować obecne regulacje prawne, uznając je za niesprawiedliwe. Przykładowo z różnych stron zgłasza-

2 Zróżnicowanie sytuacji prawno-socjalnej różnych grup zawodowych szczegółowo przedstawia I. Jędrasik-Jankowska (Zróżnicowanie prawa do emerytury w polskim prawie ubezpieczenia społecznego, [w:] Ochrona praw człowieka w świetle przepisów prawa pracy i zabezpieczenia spotecznego, pod red. A. Świątkowskiego, Warszawa 2009, s. 275 i n.).

3 Wprawdzie reforma emerytalna w 1999 roku dokonała znacznego ograniczenia dyferencjacji uprawnień emerytalnych (zob. ibidem, s. 277), jednak w świadomości społecznej fakt ten nie jest dostrzegany; w społeczeństwie zauważa się te różnice w prawie emerytalnym, które ciągle istnieją.

4 W orzeczeniu TK z dnia 28 listopada 1995 r. (sygn. akt K 17/95, OTK 1995, cz. 2, poz. 37) przyjęto, że kontrola regulacji pod względem zasady równości wymaga ustalenia, czy możliwe jest wskazanie wspólnej istotnej cechy faktycznej lub prawnej uzasadniającej równe traktowanie adresatów danej normy. Ustalenie to musi być dokonywane w oparciu o cel i ogólną treść przepisów, w których jest zawarta kontrolowana norma (orzeczenie z dnia 3 września 1996 roku, sygn. akt K 10/96, OTK ZU 1996, nr 4, poz. 33). Jeżeli kontrolowana norma traktuje odmiennie adresatów charakteryzujących się wspólną cechą istotną, to mamy do czynienia z odstępstwem od zasady równości. Nie zawsze jest to równoznaczne $\mathrm{z}$ istnieniem dyskryminacji lub uprzywilejowania sprzecznych z zasadą równości (orzeczenie TK z dnia 17 czerwca 2014 roku, sygn. akt P 6/12, OTK 62/6/A/2014). 
ne są oczekiwania, aby do ustawy o systemie ubezpieczeń społecznych włączyć rolników. Trudno bowiem uznać, że sprawiedliwym jest pozostawienie uprzywilejowanych zasad kształtowania uprawnień emerytalnych dla rolników, którzy dysponują areałem średnich i wielkich gospodarstw rolnych. W realnych stosunkach gospodarczych rolnicy ci są bliżsi pojęciu ,,przedsiębiorcy” niż osoby samozatrudnione, które de lege lata pozostają ,osobami prowadzącymi pozarolniczą działalność gospodarczą" i podlegają ubezpieczeniu społecznemu na zasadach ogólnych. Nie wchodząc w nadmierną kazuistykę, należy dokonać ogólnego stwierdzenia, że wybór cech relewantnych, wyróżniających kategorie, które mają być traktowane jednakowo, tylko do pewnego stopnia może być zobiektywizowany (sprawiedliwość formalna), natomiast ustalenie poziomu różnic pomiędzy nierównymi grupami społecznymi wydaje się jeszcze trudniejsze do obiektywnego ustalenia (sprawiedliwość materialna). Czy praca wykonywana z narażeniem życia lub zdrowia uzasadnia przyznawanie preferencyjnych reguł nabywania uprawnień emerytalnych, a jeśli tak, to w jakim stopniu? Być może wystarczającym benefitem takich grup społecznych są uzyskiwane z tego tytułu wynagrodzenia lub ewentualnie zmniejszone normy czasu pracy czy też korzystanie z ubezpieczenia chorobowego i wypadkowego w sytuacjach zachodzenia ryzyk socjalnych, które moga ponadprzeciętnie częściej występować w określonych zawodach. Zachodzą rozbieżności ocen co do zakresu dyferencjacji, czyli wyboru grup równego traktowania, które mogą być pogłębione przez różne oceny co do sposobów normowania sytuacji tych grup, w tym zakresów różnego uprzywilejowania. Należy zatem skonstatować, że zawsze będą istnieć spory co do formuły sprawiedliwości ${ }^{5}$, która ma mieć zastosowanie w unormowaniach prawnych. Zwolennicy bardziej socjalnego traktowania ubezpieczonych mogą dążyć do formuły „każdemu równo” lub „każdemu według potrzeb”, choć typowa dla ubezpieczenia społecznego jest jednak formuła „każdemu według wkładu" - składkowego lub wkładu pracy. Osoby doceniające rolę społeczną określonych grup, takich jak sędziowie czy prokuratorzy, opowiadać się będą za formułą ,każdemu według zasług”, mniej lub bardziej zbliżając ich ochronę socjalną do merytokracji. Te zróżnicowane opinie, na czym powinny polegać sprawiedliwe materialne emerytury, prowadzą niechybnie do nierozwiązywalnego sporu co do różnych koncepcji emerytur, a więc konstrukcji świadczenia oraz sposobu ich finansowania, w tym normowania wieku emerytalnego. Spory te powinny być rozwiązywalne na gruncie Konstytucji ${ }^{6}$, lecz i ta podlega możliwości zmiany, stąd

5 Pojęcia „formuły sprawiedliwości” stosowane są w pracy Ch. Perelmana (O sprawiedliwości, Warszawa 1959, s. 37) oraz przyjęte później w twórczości Z. Ziembińskiego (O pojmowaniu sprawiedliwości, Lublin 1992, s. 93 i n.)

6 Ważnym instrumentem Trybunału Konstytucyjnego wydaje się orzekanie o dopuszczalnych odstępstwach od zasady równości, które odpowiadają zasadzie sprawiedliwości społecznej. Zachodzi to w razie spełnienia trzech wymogów, a mianowicie: relewantności, proporcjonalności oraz powiązania z innymi normami, zasadami lub wartościami konstytucyjnymi. Szczególne zna- 
na problematykę warto spojrzeć szerzej. Nie mogąc przedstawić jednoznacznych kryteriów, w jakich okolicznościach określa się emerytury na zasadach sprawiedliwych materialnie, poza tymi, które funkcjonują w orzecznictwie krajowych trybunałów konstytucyjnych, należy podjąć próbę ustalenia pewnego klucza rozumienia sprawiedliwości materialnej. Inspirujące w tym zakresie jest twierdzenie B. Pascala, który zauważając, że ,sprawiedliwość podlega sporom, siła jest bardzo jasna i bezsporna”, wskazuje, że „nie mogąc zdziałać, aby to, co jest sprawiedliwe, było silne, sprawiono, aby to, co silne, było sprawiedliwe"7. W myśli tej nie ma jedynie afirmacji dla sprawiedliwości formalnej opartej na sile aparatu państwowego, ale również dla sprawiedliwości materialnej opartej na sile. Chodzi o różnie rozumiane siły: siłę polityczną narodu, który przez wybory demokratyczne kształtuje prawo jako sprawiedliwe oraz siłę przekonywania jednych osób i partii sprawujących mandat do stanowienia prawa, realizowaną wobec pozostałych, korzystających z tego mandatu, czy też siłę ekonomiczną państwa, ludności i przedsiębiorstw, która sprawia, że pewne unormowania prawne są silne lub stają się bezsilne i słabe. Znaczenie innych sił formalnych i nieformalnych można w tym miejscu pominąć. Spostrzeżenie to ma wskazywać, że to określona siła lub siły wpływają na to, że określone unormowania mogą przestać obowiązywać jako niesprawiedliwe materialnie i może nastąpić nowy wybór określonych grup jednakowego traktowania w prawie emerytalnym oraz formuł kształtowania ich sytuacji prawnej, który dopiero będzie uznawany za sprawiedliwy materialnie. Wydaje się nawet, że siła polityczna ma większe znaczenie niż uznawane za obowiązujące wzorce moralne wskazujące na jaskrawą lub nietolerowaną nierówność jako niesprawiedliwość materialną. Wzorce moralne implementowane w prawie muszą być wszak podzielane przez prawodawcę przy określaniu ustawy zasadniczej i w ustawodawstwie zwykłym, stąd wywodzą się z określonej siły politycznej. Z kolei siła ekonomiczna warunkuje możliwe formuły sprawiedliwości materialnej, która może być niewystarczająca lub pozostawiać spore nierówności i przekonania, że należne jest więcej sprawiedliwości, lecz brakuje sposobu na jej realizację albo istniejący sposób kreuje więcej szkód, niż miałby przynieść korzyści i usprawiedliwienia z tytułu większego wyrównania. Należy więc ustalić, że sprawiedliwe materialnie jest to, za czym stoi wystarczająca siła, która decyduje o akceptowanej formule sprawiedliwości i możliwości jej realizacji w prawie, co nie może jednak nigdy legitymować naruszenia praw podstawowych wynikających z godności człowieka. Sprawiedliwość materialna w prawie emerytalnym, która realizuje funkcję redystrybucyjną, odnosi się do takiego podziału korzyści i ciężarów w społeczeństwie, który jest poparty określonym konsensem co do

czenie dla uznania wyjątków od zasady równości mają właśnie wartości współkonstytuujące zasadę sprawiedliwości społecznej, takie jak solidarność społeczna i bezpieczeństwo socjalne. Zob. orzeczenie TK z dnia 17 czerwca 2014 roku, sygn. akt P 6/12, OTK 62/6/A/2014.

B. Pascal, Myśli, Warszawa 2001, s. 124. 
formuły sprawiedliwości, określającym w jakim stopniu akceptuje się nierówności w odniesieniu do sytuacji socjalnej (dyferencja), a od jakiego stopnia już ich się nie toleruje (dyskryminacja) ${ }^{8}$.

Korzystając z dookreślonego rozumienia sprawiedliwości materialnej, należy zadać pytanie, czy obecne prawo emerytalne jest silne w realizacji założonych formuł sprawiedliwości materialnej. Istniejące roszczenia o wypłatę emerytur zgodnie z treścią nabytych praw emerytalnych są gwarantowane przez aparat państwa, co może wskazywać na ich siłę. Oparcie prawa emerytalnego na zasadzie roszczeniowości sięga w sposób oczywisty do siły państwa jako gwaranta realizacji świadczeń z zakresu ubezpieczeń społecznych. Zważywszy jednak na to, że podstawy ekonomiczne do pokrycia emerytur w przyszłości nie są wystarczające, należy dostrzegać problem braku dostatecznej siły, która sprawi, że prawa uzyskane przez ubezpieczonych zostaną zrealizowane. Na podstawie art. 2 ust. 3 ustawy o systemie ubezpieczeń społecznych państwo jest zobowiązane do gwarantowania wypłacalności FUS, co realizuje przez przekazywanie dotacji z budżetu państwa. Potencjał gwarancji państwa w zakresie wypłacalności emerytur ulega jednak z czasem zmniejszeniu z uwagi na stopień zadłużenia państwa (poziom długu publicznego) oraz stałe zjawisko kilkakrotnie większej wielkości deficytu budżetowego od wielkości przyrostu dochodów budżetowych w danym roku. Według prognoz Zakładu Ubezpieczeń Społecznych dotacja budżetowa oraz pożyczki do pokrycia nierównowagi funduszu emerytalnego w FUS będą oscylować w najbliższych dekadach w kwotach 45-65 miliardów rocznie, choć są opracowania, które wskazują na jeszcze gorszy scenariusz. Zakładając, że proces podwyższania wieku emerytalnego zostałby zatrzymany lub wycofany, prognoza wymaga konkretyzacji na wyższych pułapach spodziewanej nierównowagi ${ }^{9}$. Brak znaczącego zwiększenia dochodów państwa nieuchronnie będzie prowadził do braku możliwości sfinansowania emerytur w okresie zbliżonym do dekady. Rodzi to potrzeby zmian przyjętych formuł sprawiedliwości w prawie emerytalnym, które stają się nierealne.

\section{ZMIANA FORMUŁY SPRAWIEDLIWOŚCI WOBEC NIEDOBORU GROMADZONYCH ŚRODKÓW NA POKRYCIE EMERYTUR}

Prawo emerytalne nie należy do dziedzin opierających się na niezmiennych i trwałych unormowaniach. W nauce zauważa się zależność prawa socjalnego od

$8 \mathrm{Na}$ znaczenie konsensu co do formuły sprawiedliwości zwraca uwagę Z. Ziembiński (op. cit., s. 161). Autor ten wskazuje, że pozyskanie zgody odnosi się nie tylko do formuł, które mają być stosowane w przyszłości, ale także pewnego stanu wyjściowego jako sprawiedliwego lub niesprawiedliwego, a w związku z tym wymagającego korektury.

9 Por. R. Pacud, Różnicowanie składki na ubezpieczenia społeczne z uwagi na charakter i częstotliwość ryzyka socjalnego, [w:] Składki na ubezpieczenia społeczne, pod red. K. Ślebzaka, Warszawa - Poznań 2015, s. 91. 
stosunków społecznych i ekonomicznych. Gospodarcze uwarunkowania wpływają bowiem na możliwości gromadzenia środków na świadczenia socjalne, a prawo jest zmieniane $\mathrm{w}$ reakcji na zmiany ekonomiczne, finansowe czy wreszcie demograficzne. Przyczyny te legły u podstaw reformy emerytalnej z 1999 roku, kiedy stało się jasne, że dalsza kontynuacja procesu nabywania emerytur według panujących przed reformą regulacji prawnych doprowadzi do niewypłacalności państwa. Reforma doprowadziła do zmniejszenia standardowego poziomu świadczeń emerytalnych (obliczanego w relacji do pobieranych wynagrodzeń) w kolejnych pokoleniach. Wydaje się, że przemiany dokonane przez reformę można wiązać ze zmianą formuły sprawiedliwości realizowanej przez prawo. Już w teorii prawa zauważono rolę uwarunkowań ekonomicznych dla określenia formuły sprawiedliwości. Z. Ziembiński podnosi, że w okresie przemian wysuwa się najpierw radykalne hasła sprawiedliwościowe, praktycznie niemożliwe do zrealizowania, a potem koryguje się je przez uwzględnianie wpływu formuł opartych na innego rodzaju kryteriach. Dodaje, że odejście od haseł radykalnych jest wymuszane przez realia życia społecznego ${ }^{10}$. Podobnie w okresie PRL-u ustanowiono formuły świadczenia, które były wykonalne przy wysokiej stopie zatrudnienia w warunkach gospodarki socjalistycznej oraz ciągłego wzrostu demograficznego. Po zmianie tych czynników na przeciwstawne zobowiązania emerytalne państwa stały się niewykonalne, stąd dla młodszych ubezpieczonych wprowadzono mniej korzystne rozwiązania realizujące inne formuły sprawiedliwości.

Zróżnicowanie sytuacji socjalnej osób objętych reformą oraz pozostawionych poza jej działaniem w aspekcie zmiany formuły sprawiedliwości stało się już przedmiotem refleksji w nauce. Dokonuje się tego głównie w celu krytyki konstrukcji prawnej nowych emerytów (m.in. K. Antonów) ${ }^{11}$, a nie przy badaniu sprawiedliwości w relacjach między pokoleniami. Dlatego należy wskazać, że pokolenie osób urodzonych do 31 grudnia 1947 roku - w całości prawa do emerytury - a także osoby urodzone w czasie późniejszym - w tej części prawa do emerytury, która uwzględnia kapitał początkowy - korzystają z formuły ochronnej opartej na zasadzie „każdemu według wkładu (pracy)”, połączonej z formułą „każdemu według potrzeb”. Z kolei osoby pobierające emeryturę wyliczaną ze składek (proporcjonalnie do okresu pozostałego statystycznie do przeżycia) ko-

10 Z. Ziembiński, op. cit., s. 170.

${ }^{11} \mathrm{~K}$. Antonów (Zasady równości i sprawiedliwości społecznej w prawie emerytalnym, „Annales UMCS. Sectio G” 2015, Vol. LXII, z. 2) uważa, że w prawie emerytalnym niezbędne jest wzajemne uzupełnianie się zasady „,według pracy” oraz „,według potrzeb”, natomiast osobom urodzonym po dniu 31 grudnia 1948 roku daje się niemal absolutny prymat zasadzie ,według pracy”, nie licząc drobnej korekty z uwagi na uwspólniony dla mężczyzn i kobiet współczynnik ŚDTŻ. Autor ten zauważa $\mathrm{w}$ związku z tym, że w kolejnych latach ustawodawca przez objęcie ochroną osoby sprawującej funkcje rodzicielskie i opiekuńcze uzupełnia regulację prawa emerytalnego rozwiązaniami, które podkreślają solidarnościową (wspólnotową) naturę prawa ubezpieczeń społecznych. 
rzystają jedynie z formuły „każdemu według wkładu (składkowego)”. Jest ona jednak subsydiarnie uzupełniana przez formułę „każdemu według potrzeb”, czyli sytuacji, kiedy wyliczane świadczenie nie przekroczy ustawowej kwoty emerytury minimalnej. Wprowadzenie różnych grup o różnej konstrukcji uprawnienia emerytalnego, które $\mathrm{z}$ uzasadnionych powodów nie są traktowane równo, nie może stanowić zarzutu. Problem powstaje jednak post factum przy konfrontacji ze skalą różnic w wysokości realnej świadczeń pomiędzy emeryturą proporcjonalną do wynagrodzenia a emeryturą proporcjonalną do składek. W tej drugiej ogniskują w sobie problemy przerw w zatrudnieniu i niewystarczającego wzrostu wynagrodzeń, stąd różnice w poziomie ochrony socjalnej mogą okazać się nadmierne w świetle sprawiedliwości materialnej.

Na podstawie obowiązującej Konstytucji Rzeczpospolita urzeczywistnia zasady sprawiedliwości społecznej, które są pojmowane w liczbie mnogiej, gdyż nie ma jednej zasady sprawiedliwości społecznej właściwej na każdy czas. Stwierdzenie takie znajduje poparcie w poglądach J. Jończyka ${ }^{12}$, a szerzej również $\mathrm{K}$. Antonowa, który nawiązuje także do B. Wagner, przyjmując, że naturalne jest istnienie swoistej konkurencyjności formuł sprawiedliwości, a wybór (przewaga) jednej z nich zależy od warunków ustrojowych (społeczno-gospodarczych), które opierają się na założeniach aksjologicznych ${ }^{13}$. Zakładając, że nastąpi brak środków gromadzonych na pokrycie emerytur, niezbędne okaże się kształtowanie nowych formuł sprawiedliwości społecznej, wymagających pewnej relatywizacji ochrony praw nabytych. Nie można uznać za sprzeczne z zasadą sprawiedliwości ustalenie w przyszłości takich unormowań, które służą w pełniejszy sposób celom społecznym (wyrównanie nierówności społecznych) i ograniczają nadmierne różnice w poziomie ochrony socjalnej. Niewykluczone, że wprowadzenie takich formuł będzie w określonym stopniu podważać prawa nabyte, aby zrealizować cechy sprawiedliwości, która musi polegać na sile politycznej i ekonomicznej. Niesprawiedliwe nie może być więc ograniczenie części praw nabytych, jeżeli pełna realizacja wszystkich uprawnień emerytalnych będzie prowadzić do nadmiernego osłabienia budżetu państwa oraz FUS, w tym sztucznych operacji finansowych, ukrywających poziom zadłużenia. Niesprawiedliwą nie może być ta formuła sprawiedliwości rozdzielczej, która zastępuje wcześniejszą jako nierealną i niewykonalną w sytuacji braku możliwości zaciągania dalszych pożyczek przez Skarb Państwa, m.in. na cele finansowania emerytur, które nie mają pokrycia w środkach FUS i środkach budżetowych. Racjonalne stanowienie norm postępowania powinno liczyć się z zasadą imposibiulium nulla obligatio est ${ }^{14}$.

\footnotetext{
12 J. Jończyk, Prawo zabezpieczenia społecznego, Warszawa 2006, s. 27.

13 K. Antonów, op. cit.

14 Z. Ziembiński, op. cit., s. 95.
} 


\section{SPRAWIEDLIWOŚĆ MIĘDZYPOKOLENIOWA}

Reforma emerytalna z 1999 roku bazowała na ochronie zaufania do państwa, chroniąc ekspektatywy i roszczenia pochodzące z systemu wygasającego. W tym aspekcie reforma została przeprowadzona pomyślnie dla pokolenia obecnych emerytów, którzy otrzymują emerytury proporcjonalne do wynagrodzeń. Korzyści czerpią także ubezpieczeni należący do grupy pośredniej, którzy w części korzystają z dobrodziejstwa wygasającej formuły emerytalnej (emerytury mieszane, kapitał początkowy). Grupa ta jest - w rozumieniu określonej gry społecznej - wygrana, gdyż uprawnienia osób urodzonych przed 1949 rokiem, a stopniowo także osób urodzonych w latach 1949-1969, są realizowane w pełni pomimo tego, że były w całości lub odpowiedniej części nabyte w warunkach gospodarki socjalistycznej PRL, która stała się całkiem niewydolna i zbankrutowała. Finansowanie tych świadczeń następuje w nowych warunkach ekonomicznych, jednakże w sytuacji, kiedy nierównowaga funduszy emerytalnych FUS oraz rosnący dług publiczny negatywnie oddziałują na polskie państwo i gospodarkę, której rynki, w tym rynek pracy, pozwoliły i z trudem dalej pozwalają ponosić ciężar finansowania emerytur ukształtowanych jeszcze w PRL-u. Kierując się sprawiedliwym kształtowaniem sytuacji prawno-socjalnych przyszłych i obecnych emerytów zakładano przy reformie z 1999 roku, że nastąpi wzrost wynagrodzeń, który pozwoli uzyskać w miarę godne emerytury liczone na podstawie składek, a ubezpieczeni będą sięgać do dodatkowych zabezpieczeń emerytalnych. Niezbyt zauważalny jest wzrost realnych wynagrodzeń osiąganych przez dolną połowę zarobkującego społeczeństwa, nie nastąpił również przyrost indywidualnych lub grupowych form zabezpieczenia emerytalnego ${ }^{15}$. W najbliższych latach odrodzi się zjawisko dwóch portfeli emerytalnych, tym razem odwrócone, gdyż to starsi emeryci będą korzystać z wyższych świadczeń, co mogą dostrzec przyszli emeryci, obserwując przebieg ubezpieczenia wyliczany przez ZUS przez formułę emerytury hipotetycznej. Należy więc skłaniać się do tezy, że ograniczenie uprawnień emerytalnych dla młodszych pokoleń nie powiodło się i skutki reformy emerytalnej z 1999 roku będą odczuwać osoby z niższym kapitałem początkowym. Według przyjętej konwencji gry społecznej oznacza to, że przyszli emeryci są przegrani. Proces podwyższania wieku emerytalnego wywołuje dodatkowo negatywne odczucia co do tego „przegrania”. Rodzi to zasadnicze pytania o sprawiedliwość w relacjach miedzypokoleniowych, a także wątpliwości, czy ścisłe przestrzeganie „umowy międzypokoleniowej”, podpartej konstytucyjną ochroną praw nabytych, nie prowadzi do niesprawiedliwości. Co ciekawe, podobne, aczkolwiek

15 Zob. porównanie IKE, IKZE oraz PPE: R. Pacud, Indywidualne Konta Zabezpieczenia Emerytalnego, „Praca i Zabezpieczenie Społeczne” 2011, nr 11, s. 21-26. 
bardziej dosadne, konkluzje feruje na gruncie niemieckiego systemu emerytalnego H.F. Zacher. Autor ten formułuje bowiem tezę, że obecny stan wykonania „umowy międzypokoleniowej” w Niemczech uzyskuje najszerszy wymiar prawnego i politycznego zabezpieczenia jedynie dla osób starszych, przyjmując, że ,gdy idzie o średnie pokolenie, to tu da się jeszcze wyróżnić ochronę ich ekspektatyw nabytych w zamian za składki. Natomiast dla pokolenia najmłodszego nie ma nic porównywalnego - nic" ${ }^{16}$. Czy takie zróżnicowanie można uznać za sprawiedliwe?

Rozpatrywanie znaczenia sprawiedliwości w aspektach międzypokoleniowych powinno być odnoszone do mechanizmu umowy społecznej, która ma regulować relacje między przyszłymi a obecnymi emerytami. Umowa społeczna to wywiedziony z teorii umowy społecznej „niepisany kontrakt międzygeneracyjny", respektowany z pokolenia na pokolenie, który znajduje uzasadnienie w tym, że każde pokolenie przechodzi fazy rozwojowe i będzie kiedyś stare, a więc znajdzie się w takiej samej potrzebie ${ }^{17}$, stąd przy zachowaniu wzajemności może liczyć, że kolejne pokolenia $(\mathrm{n}+2)$ uczynią tak samo, finansując „W przyszłości” emerytury tego pokolenia $(\mathrm{n}+1)$, które „dziś” finansują emerytury najstarszych żyjących osób ze wspólnoty ubezpieczeniowej (n). Zasada umowy społecznej stała się podstawą finansowania repartycyjnego ubezpieczenia emerytalnego. W kontekście finansowym w umowie międzypokoleniowej chodzi o zagwarantowanie praw emerytów w podziale środków uzyskiwanych z gromadzonych na bieżąco składek, a z uwagi na reguły realizacji praw emerytalnych - także z funduszu emerytalnego, do którego znaczną cześć dopłaca budżet państwa. Podstawa do realizacji ekspektatyw i tych roszczeń wynika z doktryny praw nabytych. Gwarancjami realizacji umowy społecznej, zwanej na gruncie prawa emerytalnego także „umową międzypokoleniową”, są konstytucyjnoprawne reguły ochrony praw nabytych, które przysługują określonym osobom w relacji wobec państwa. Warto jednak zauważyć, że koncepcja własnościowa ochrony ekspektatyw i roszczeń, wysnuta w niemieckim orzecznictwie konstytucyjnym, odnosi się głównie do relacji międzypokoleniowej oraz podziału środków służących finansowaniu emerytur i raczej nie określa sytuacji prawnej ubezpieczonych (uprawnień) odnoszonej do sytuacji prawnej państwa (obowiązek). Ochrona praw nabytych polega na ochronie prawa do udziału w podziale środków, które powinno być mierzalne składkowym wkładem zainteresowanego ${ }^{18}$.

16 Por. H.F. Zacher, Uwagi o solidarności międzypokoleniowej, [w:] Z aktualnych problemów prawa pracy i prawa socjalnego, pod red. H. Szurgacza, Wrocław 2009, s. 256.

17 S. Golinowska, Polityka społeczna państwa w gospodarce rynkowej. Studium ekonomiczne, Warszawa 1994, s. 35.

18 K. Ślebzak, Ochrona emerytalnych praw nabytych, Warszawa 2009, s. 186. 
Łącząc zatem umowę międzypokoleniową z finansowaniem repartycyjnym oraz gwarantowaniem jej realizacji przez zasady ochrony praw nabytych, należy zapytać, czy ukształtowany wzorzec normatywny określa sytuację prawno-socjalną grup przyszłych i obecnych emerytów w sposób sprawiedliwy. W tym obszarze należy pytać o sprawiedliwość międzypokoleniową. Zdaniem Z. Ziembińskiego takie pojęcie sprawiedliwości jest ważne wtedy, jeżeli ludzie z jednego pokolenia mogą wpływać na los pozostałych pokoleń. Niewątpliwie taki skutek ma stanowienie ubezpieczenia emerytalnego finansowanego repartycyjnie. Powstaje więc kwestia, czy ciężary, którymi obarczono przyszłe pokolenia, nie zostały ustalone nadmiernie. Na umowę społeczną teoretycznie powinno się spojrzeć jak na ugodę partnerów społecznych. C. Znamierowski, badając różne aspekty w teorii państwa, wskazuje, że w ugodach, które stanowią tytuł do władania i postawy władczej, z biegiem czasu powstaje tendencja u obu partnerów do zmniejszania swych zobowiązań, a zwiększania ich po stronie przeciwnej ${ }^{19}$. Umowa międzypokoleniowa jest jednak ugodą takiego typu, że młodsze pokolenie zawsze jest pozbawione głosu, nie może sprzeciwić się kreowaniu nadmiernych ciężarów przez przyszłe pokolenia, dlatego F.H. Zacher formułuje krytykę umowy międzypokoleniowej jako pełną sprzeczności, choćby takiej, że nie ma partnerów w takiej umowie, którzy mogliby uzgadniać stanowiska, a nadto, że stosunek pokoleń do każdej z form zabezpieczenia emerytalnego kształtuje się inaczej (dyferencjacja ustawodawstwa emerytalnego) ${ }^{20}$. Pomimo tego nie można całkiem odrzucić koncepcji niepisanej umowy społecznej w ubezpieczeniu emerytalnym, choć jej przydatność jest większa w analizie ekonomicznej. Pozostają bowiem celne ustalenia W. Szuberta, który postrzega umowę społeczną w ubezpieczeniu emerytalnym jako długoterminową operację finansową określającą rozkład obciążeń i świadczeń między różnymi generacjami w perspektywie wieloletnich okresów ${ }^{21}$. Obecna rzeczywistość wpisuje się jednak w obserwacje C. Znamierowskiego - bez odpowiedniego oporu siły pokolenie starsze mogło zwiększać ciężar pokolenia młodszego jako partnera umowy społecznej po stronie przeciwnej.

Zmiany wprowadzane przez reformę emerytalną lokują w niekorzystnej sytuacji przyszłe pokolenia, które otrzymają emerytury w przeciętnie niższej wysokości. Posługując się językiem zobowiązań, obecne pokolenia będą zobowiązane do spłaty większych długów emerytalnych niż wielkość długu, jakim zostaną obciążone kolejne pokolenia, które będą finansować emerytury ustalone już w niższej wysokości. Stan nadmiernego zróżnicowania sytuacji ekonomicznej pomiędzy pokoleniami pogłębia rosnący dług państwa, który tak jak ubezpiecze-

19 C. Znamierowski, Rozważania o państwie, Warszawa 1999, s. 115.

20 Por. H.F. Zacher, op. cit., s. 254-255.

21 W. Szubert, Ubezpieczenie społeczne, Warszawa 1987, s. 232. 
nie emerytalne jest również zaciągany na koszt przyszłych pokoleń. Wobec trudności ze sfinansowaniem obecnych emerytur najbardziej oczywistym pytaniem staje się kwestia, czy sprawiedliwe będzie zwiększanie podatków i składek celem pokrycia większych potrzeb FUS. Po części podwyższanie podatków i składek będzie nieskuteczne, gdyż poszczególne grupy obywateli będą potrafiły „uciec” od zwiększonych obowiązków przez dozwolone prawem kształtowanie sytuacji faktycznej podlegającej normowaniu przez prawo podatkowe i prawo ubezpieczeń społecznych, tudzież działania niedozwolone prawem. Po części jednak działania te uzyskają skutek, a wtedy wzrost podatków i składek będzie powiększać skalę ubóstwa i pogarszać sytuację przedsiębiorstw. Konieczność podwyższania podatków oraz spłata przez obecne pokolenie większych zobowiązań emerytalnych, w porównaniu do tego, co w perspektywie otrzyma przez wzajemną spłatę od wstępujących pokoleń, można uznać za przejaw braku sprawiedliwości międzypokoleniowej.

Innym bardzo trudnym pytaniem pozostaje kwestia, czy nie powinna nastąpić korekta w myśl zasady sprawiedliwości społecznej ze strony lepiej uposażonych emerytów na rzecz najsłabszych obywateli i rodzin. Takie pytania będą narastać, gdyż układ relacji międzypokoleniowych może rodzić nierówności, które są nietolerowalne. Negatywne skutki reformy emerytalnej z 1999 roku (nierówności poziomu emerytur) będą odczuwać osoby z niższym kapitałem początkowym. Zmniejsza się odczucie bezpieczeństwa emerytalnego związanego $\mathrm{z}$ brakiem przekonania różnych grup respondentów, czy otrzymają godne emerytury. W pewnym stopniu przyczynia się to również do emigracji. Osoby w grupie wiekowej 20-40 lat w znacznej części już „wypowiedziały” „umowę międzypokoleniową" istniejącą w Polsce przez wyjazd za granicę. H.F. Zacher zauważa inny aspekt braku realizacji umowy międzypokoleniowej - wzbranianie się od wychowania dzieci w średnim pokoleniu spowodowało zmiany w ilościowej i jakościowej proporcji w stosunku do obu pokoleń. Konkluduje dalej, że zmiany w świecie pracy, przepływie kapitału, globalizacja, a także wydłużanie się życia oraz wzrost kosztów opieki medycznej prowadzą do tego, że umowa międzypokoleniowa jako mechanizm samonośny ubezpieczenia emerytalnego doznała implozji; rzadziej mówi się w Niemczech o ,umowie międzypokoleniowej”, a więcej o „sprawiedliwości międzypokoleniowej”22. Przychodzi więc i w Polsce pora na dyskusję o sprawiedliwości wyrównawczej, która będzie chronić pokolenie przyszłych emerytów przed ruiną państwa i gospodarki, do której przyczyniać się będzie pełna realizacja emerytur w kolejnych dwóch dekadach. 


\section{WNIOSKI}

Przeprowadzona analiza pozwala stwierdzić, że sprawiedliwość w prawie nie może polegać na unormowaniach niewykonalnych, niemożliwych, a przez to słabych. Siła polityczna i siła ekonomiczna, a także inne siły, decydują w dużej mierze o tym, co jest sprawiedliwe; wpływają na to, że inne - mniej korzystne dla określonych grup unormowania - również mogą być uznane za sprawiedliwe materialnie. To zmiana sił powoduje zmianę ustalanych formuł sprawiedliwości wyrównawczej na bardziej ochronne lub mniej ochronne. Dalej wykazano, że przestrzeganie ustalonych norm prawa emerytalnego może prowadzić do niesprawiedliwości materialnej w ujęciu międzypokoleniowym z uwagi na to, że młodsi ubezpieczeni, którzy finansują wyższe emerytury osób z wygasającego systemu emerytalnego, nie otrzymają równie wysokich emerytur. Wiek emerytalny nie musi mieć tak dużego znaczenia w tej kwestii, gdyż ze względu na postęp medyczny młodsze pokolenie może żyć dłużej, choć tego dziś nikt nie jest w stanie z całą pewnością stwierdzić. Stan nietolerowanej nierówności może powiększyć się przy zwiększeniu podatków i składek. Dlatego szukając rozwiązań na przełamanie obserwowalnych zjawisk niesprawiedliwości międzypokoleniowej, należy zmierzać do określenia innego rozkładu ciężarów w grupach społecznych. Obiektywny brak możliwości realizacji prawa do emerytury w pogarszających się warunkach ekonomicznych - jeżeli taki nastąpi lub ewentualnie zostanie niepodważalnie stwierdzony z konkretyzacją czasu niewypłacalności - powinien sprawić, że dopuszczalne dla prawodawcy będą zmiany ingerujące w prawa nabyte.

$\mathrm{Na}$ zakończenie rozważań trudno przedstawić choćby kierunki możliwych reform, które przywróciłyby międzypokoleniową sprawiedliwość, choć można je zasygnalizować. Zasadniczo powinno się ograniczać redystrybucję na rzecz pokolenia obecnych emerytów. Nowe unormowania powinny zmierzać do zwiększenia preferencji dla osób, które realizują umowę międzypokoleniową w aspekcie wychowawczym, chociaż nie może być to odbierane jako moralna dezaprobata dla rodzin lub osób wychowujących jedno dziecko lub żyjących bez potomstwa. FUS winien być uznawany za dobro wspólne wszystkich pokoleń, stąd potrzebna będzie ochrona przed jego niewypłacalnością przez mechanizmy waloryzacji kwotowej ograniczające wzrost nominalnej wysokości najwyższych emerytur. Do dyskusji pozostają nowe rozwiązania prowadzące do zawieszenia lub redukcji części najwyższych emerytur, co stanie się niezbędne w sytuacji braku możliwości sfinansowania wszystkich emerytur. Potrzebne staje się przywrócenie sprawiedliwości międzypokoleniowej nie tylko $\mathrm{w}$ relacjach emerytalnych, ale także przez nowe rozwiązania w dziedzinie ubezpieczeń rodzinnych (zasiłki dla dzieci finansowane ze składek wszystkich osób, które nie muszą utrzymywać osób małoletnich) oraz ubezpieczeń zdrowotnych (pokrycie kosztów opieki zdrowotnej w grupach, które je tworzą, czyli osobno dla grup emerytów oraz pozostałych pokoleń). 


\section{BIBLIOGRAFIA}

Antonów K., Zasady równości i sprawiedliwości społecznej w prawie emerytalnym, „Annales UMCS. Sectio G” 2015, Vol. LXII, z. 2.

Golinowska S., Polityka społeczna państwa w gospodarce rynkowej. Studium ekonomiczne, Warszawa 1994.

Jędrasik-Jankowska I., Zróżnicowanie prawa do emerytury w polskim prawie ubezpieczenia spotecznego, [w:] Ochrona praw człowieka w świetle przepisów prawa pracy i zabezpieczenia społecznego, pod red. A. Świątkowskiego, Warszawa 2009.

Jończyk J., Prawo zabezpieczenia społecznego, Warszawa 2006.

Pacud R., Indywidualne Konta Zabezpieczenia Emerytalnego, „Praca i Zabezpieczenie Społeczne” 2011, nr 11.

Pacud R., Różnicowanie składki na ubezpieczenia społeczne z uwagi na charakter i częstotliwość ryzyka socjalnego, [w:] Składki na ubezpieczenia społeczne, pod red. K. Ślebzaka, Warszawa - Poznań 2015.

Pascal B., Myśli, Warszawa 2001.

Perelman Ch., O sprawiedliwości, Warszawa 1959.

Szubert W., Ubezpieczenie społeczne, Warszawa 1987.

Ślebzak K., Ochrona emerytalnych praw nabytych, Warszawa 2009.

Zacher H.F., Uwagi o solidarności międzypokoleniowej, [w:] Z aktualnych problemów prawa pracy i prawa socjalnego, pod red. H. Szurgacza, Wrocław 2009.

Ziembiński Z., O pojmowaniu sprawiedliwości, Lublin 1992.

Znamierowski C., Rozważania o państwie, Warszawa 1999.

\section{SUMMARY}

Different concepts of justice in pension insurance are discussed in this article. It indicates that a given formula of justice must be adopted in any legal system and may be changed if the political and economic powers change. In this context it is viewed that the 1999 pension reform in Poland was conducted with social approval because the economic stability of pension system and pension rights in particular were endangered. That provoked change of the justice formula for young generations, whose legal consequences can be seen only nowadays. Justice that had been established "according to contribution of work" and "according to needs" was replaced by justice "according to contribution". After years it has resulted in huge differences among generations regarding their social situation. As the pension system will get more and more unsustainable, it is necessary to make the choice which solution is just: to implement some burdens that are financed by the generation of current pensioners or to increase the pay-roll taxes or taxes.

Keywords: pension insurance; justice; formula of justice; generations; economics of pension 